\title{
THE MOSAICS OF DURRES AMPHITHEATRE: AN ASSESSMENT USING TECHNICAL OBSERVATIONS
}

\author{
ELISABETTA NERI
}

Les mosaïques de l'amphithéâtre de Durres : une réévaluation par un examen technique

\begin{abstract}
La chronologie (VI', IX , post-IX siècle), l'origine culturelle (matrice romane ou byzantine) et l'interprétation de la mosaïque de la chapelle de l'amphithéâtre de Durres ont été longtemps débattues. L'article propose une analyse nouvelle de cette mosaïque en la replaçant dans son contexte architectural grâce à l'étude des techniques de mise en cuvre et l'analyse physico-chimique des tesselles.

La chronologie des tesselles se place entre le $\mathrm{VI}^{e}$ et le $\mathrm{VII}^{e}$ siècle. Cette datation differe toutefois de celle de la chapelle qui n'est pas bâtie avant le VII siècle et qui, pendant le IX $X^{e}$ siècle, connaît une phase décorative qui précède la mosaïque. Est ainsi proposée l'hypothèse soit du remploi de tesselles provenant d'une autre mosaïque, soit du déplacement tardif d'une mosaïque paléochrétienne provenant d'un autre site de la ville. [Trad. ???]
\end{abstract}

\section{Byzantine mosaics of Durres amphitheatre}

The wall mosaics of a small chapel inserted into the Roman amphitheatre of Durres are an important Byzantine decoration, for which the chronology, the provenance of the mosaicists, the iconographical interpretation and the ideological framework are widely debated. The archaeological and iconographical arguments have produced a multiplication of subjective interpretations about the historical context of the genesis of the mosaic.

The interpretation of these mosaics is complicated by the absence of comparative examples of Byzantine wall mosaics in Illyricum and by the nature of Durres: the terminus of via Egnatia - connecting Rome to Constantinople via Thessaloniki -, a place where the cultural currents of East and West meet.
Two recent works on this mosaic corroborate the Byzantine (and not western) origin of the iconographical architecture, but propose opposite interpretations of the chronology.

K. Bowes and J. Mitchell attribute them to post $9^{\text {th }}$ $11^{\text {th }}$ centuries. based on the architectonical context and the iconographical interpretation of wall and roof paintings, which the mosaics overlap. ${ }^{1}$ Conversely, L. Miraj favours an attribution to the $6^{\text {th }} 7^{\text {th }}$ centuries, based on an iconographic reading of the better preserved southern panel, in particular on a study of the imperial costume. ${ }^{2}$

1. Bowes, Mitchell 2009, pp. 569-595.

2. Miraj 2013, pp. 60-71. 
This paper resumes the principal arguments of the different positions and proposes, by combining a new in situ observation of the mosaic technique and the analysis of the glass tesserae, a chronology of the glass tesserae and a hypothesis on their provenance and that of the mosaicists.

\section{Architectonical context and description of the mosaics}

The main chapel, containing the mosaics, is located under one vomitorium of the second elliptical gallery in the amphitheatre of Durres, situated in the west part of the Byzantine wall (Figs. 1-2). This chapel consists of a single nave with an eastern apse outside the wall of the arena; the plan is quadrangular, narrowing to the east, according to the shape of the radial gallery. Two other chapels, dated to around the $6^{\text {th }}-7^{\text {th }}$ centuries, are documented in the amphitheatre marking a complex Christianization program of the pagan space, as also seen in other cases. ${ }^{3}$

The chapel was constructed after the abandonment of the amphitheatre, which probably occurred after the earthquake of 345 and after the interruption of gladiator games, according to the imperial laws. ${ }^{4}$ Materials from the amphitheatre were recycled to build the chapel: stone slabs and bricks were re-used in the pavement and the altar was constructed in opus mixtum, re-using a sixth-century Christian funerary inscription.

The first marker of the defunctionalisation of the amphitheatre are the graves found near the chapel in the galleries. The majority are simple graves dug in the earth and covered with tiles, oriented to the north or south and sometimes with objects similar to those of the Komani civilization. ${ }^{5}$ These fibulas and rings are commonly dated $6^{\text {th }}-7^{\text {th }}$ centuries, but a recent work showed the difficulty in proposing a precise date, and the extended use of these artefacts until the $10^{\text {th }}$ century. ${ }^{6}$ A grave located at the centre of the chapel is dated to the $10^{\text {th }}$ century, according to bronze coins (969-976).

The chronology of the construction of chapel is commonly assigned to the $7^{\text {th }}$ century by the date of the graves, the allegedly Heraclian brick stamp in the western alcove floor and the sixth-century Christian inscription re-used in the altar. Although, the stylistic affinities of the mosaics with late antique wall mosaics are another argument frequently used to propose a $6^{\text {th }}-7^{\text {th }}$ range, no

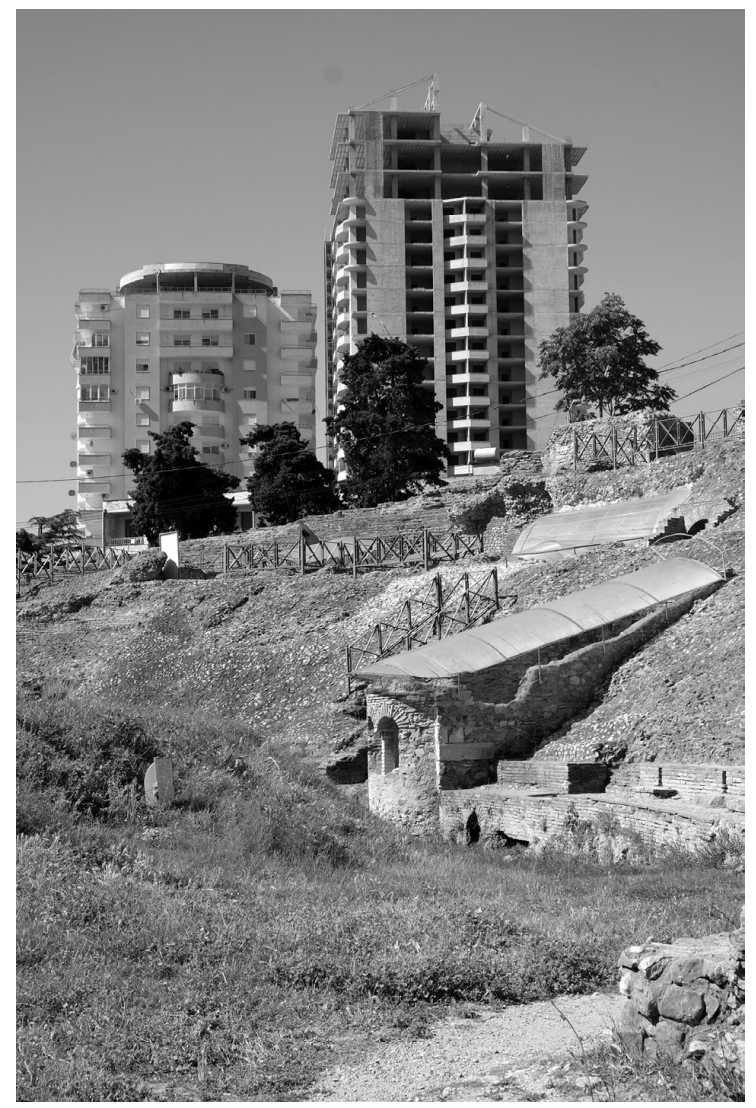

Fig. 1 - The amphitheatre Durres chapel (photo D. Dubois).

objective proof is available to suppose this chronology of the building. K. Bowes and J. Mitchell suppose that the above-mentioned elements are a terminus post quem, because they have documented a seventh-century abandonment phase of the amphitheatre, ${ }^{7}$ and propose a tenth-century chronology for the construction of the chapel, based on coins in the main tomb and medieval ceramics ( $9-10^{\text {th }}$ centuries) found outside the chapel.

The last mention of the chapel in the written sources is a letter written by Charles I to Johan Scoct and Guarin Shovel in 1280. The chapel was probably used until the Ottoman period, from when the most recent ceramics found in the demolition layers are dated. ${ }^{8}$ It was abandoned afterwards, until the excavation of Toçi in $1966^{\circ}$

3. For example, in Tarragona and Aphrodisias (Godoy 1999 with references and comparisons).

4. The munera gladiatoria are prohibited by Honorius: CTh 15.12.1; 9.40.8, Theodoret, Historia Ecclesistica, 5.26.

5. Anamali 1993, pp. 435-446; Miraj 1988, pp. 264-265.

6. Nallbani 2002.

7. Bowes, Hoti 2003, p. 388.

8. Toçi 1971; 1975; Santoro et al. 2005, p. 771. This hypothesis is corroborated by the fact that the monumental tomb outside the chapel is used until the $14^{\text {th }}$ century.

9. Toçi 1971 . 

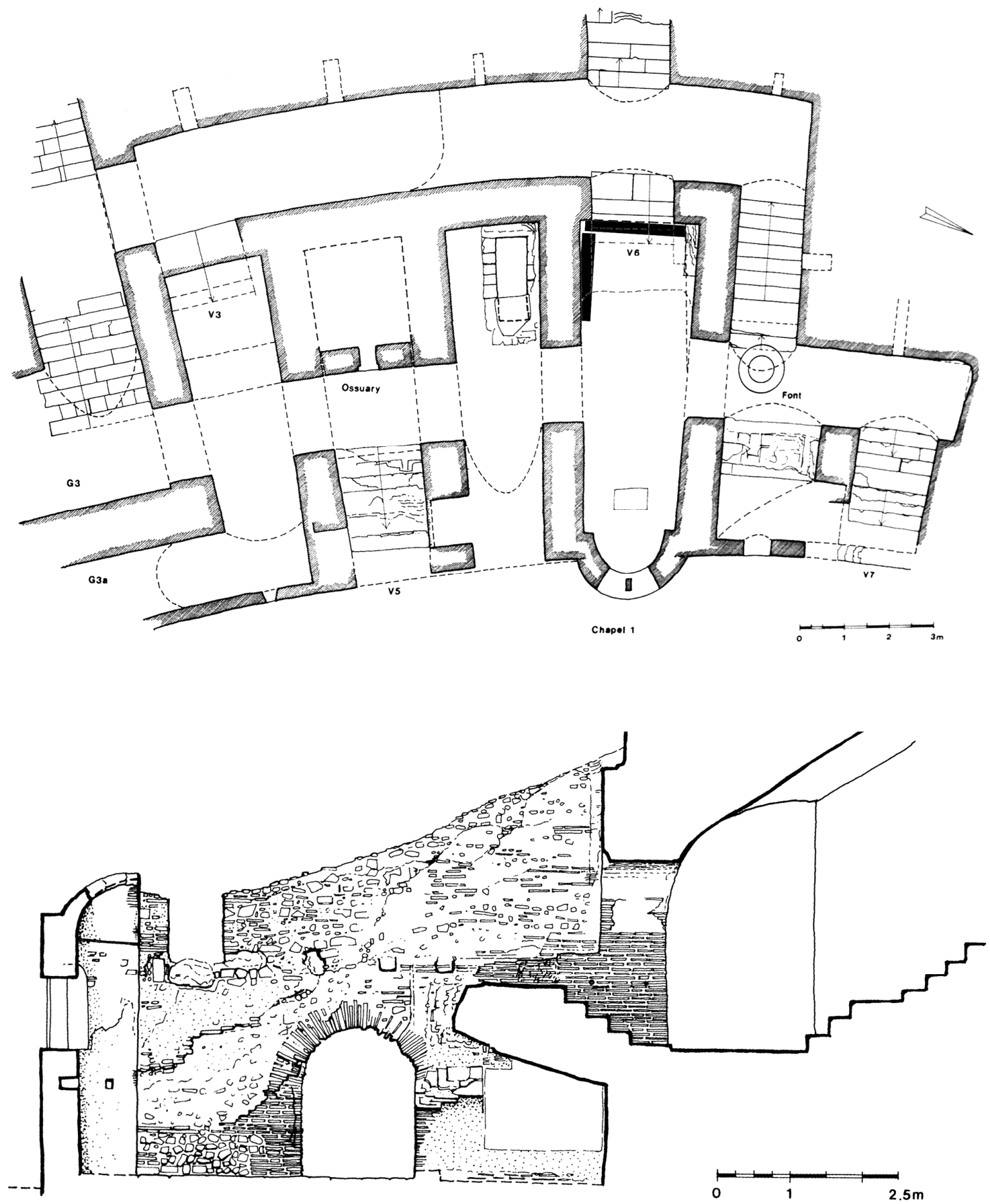

Fig. 2 - Plan of the amphitheatre chapel with underlined the localisation of the mosaics. 